\title{
Contribution of regulatory $T$ cells to immune tolerance and association of microRNA-210 and Foxp3 in preeclampsia
}

\author{
JIYING CHEN $^{1,2}$, LIJIAN ZHAO ${ }^{1}$, DENGCHUAN WANG $^{2}$, YANBIN XU $^{1}$, \\ HAIJIE GAO $^{1}$, WENQING TAN ${ }^{2}$ and CHENHONG WANG ${ }^{1}$ \\ ${ }^{1}$ Department of Obstetrics and Gynecology, Maternal and Children's Hospital of Shenzhen City, \\ Southern Medical University, Shenzhen, Guangdong 518000; ${ }^{2}$ Department of Obstetrics and Gynecology, \\ Shenzhen Longhua District Central Hospital, Shenzhen, Guangdong 518110, P.R. China
}

Received April 6, 2018; Accepted November 2, 2018

DOI: $10.3892 / \mathrm{mmr} .2018 .9733$

\begin{abstract}
Increasing evidence suggests that an exaggerated maternal systemic inflammatofrery response may play a central role in the pathogenesis of preeclampsia (PE). Considering the growing evidence on microRNAs (miRNAs) and tissue-specific regulators of gene expression, we investigated the potential association of miR-210 and forkhead box p3 (Foxp3) in preeclamptic patients. Serum levels of the cytokines interleukin (IL)-6, IL-10, IL-17, and transforming grown factor- $\beta 1$ were detected with ELISA. Reverse-transcription-quantitative polymerase chain reaction was performed to detect mRNA expression for maternal placenta retinoic acid-related orphan receptor C, Foxp3 and miRNA (miR)-210. Foxp3 protein expression was evaluated by western blot analysis. Serum levels of cytokines IL-10 were significantly lower in preeclamptic patients than in normal pregnant women. mRNA expression of Foxp3 was significantly lower in placenta of PE. mRNA expression of miR-210 was significantly increased in PE. Results of western blot analysis indicated that Foxp3 protein expression was lower in PE than in normal pregnant women. Our data suggest that PE manifests as a decreased number of regulatory $\mathrm{T}$ cells (Tregs), which regulate maternal tolerance of the fetus. In placenta from women with PE, compared with normal pregnant women, mRNA expression of Foxp3 was significantly decreased, and expression of miR-210 was significantly increased.
\end{abstract}

\section{Introduction}

Preeclampsia (PE) is characterized by hypertension and proteinuria. The condition increases the risk for maternal and

Correspondence to: Dr Chenhong Wang, Department of Obstetrics and Gynecology, Maternal and Children's Hospital of Shenzhen City, Southern Medical University, 2004 Hongli Road, Futian, Shenzhen, Guangdong 518000, P.R. China

E-mail: szwangchenhong@vip.163.com

Key words: regulatory $\mathrm{T}$ cells, microRNA-210, forkhead box p3, preeclampsia perinatal morbidity and mortality, with worldwide incidence of approximately 4-6\% (1). Despite extensive research, the etiology and pathogenesis of PE are not completely understood. Previous research has shown that that placental tissue but not the fetus is necessary for the development of PE. The condition is cured upon delivery of the placenta, which underscores the indispensable role of this tissue in the pathophysiology of PE (2).

The consensus reached at a recent workshop sponsored by the National Institute of Child Health and Human Development/National Institutes of Health is that preeclampsia is a multifactorial disease whose pathogenesis is not solely vascular, genetic, immunologic, or environmental but a complex combination of factors (3). In PE, excessive activation of peripheral blood leukocytes is associated with exaggerated innate and adaptive immune responses, which may interfere with normal progression of a pregnancy (4).

Regulatory T cells (Tregs) are a specialized subpopulation of $\mathrm{T}$ cells that act as potent suppressors of inflammation to prevent autoimmunity and graft rejection (5). Tregs prevent activation of maternal $\mathrm{T}$ cells against fetal cells; this protection of the fetus from the maternal immune system has been widely reported in both mice and humans (6-8). A reduction in maternal Treg populations could prevent immunological tolerance of the fetus and has been associated with obstetrical complications, such as miscarriage, $\mathrm{PE}$ and preterm labor (9-14).

Tregs comprise Th1 and Th 2 cells. Tregs expressing forkhead box p3 (Foxp3) help to maintain immune tolerance and homeostasis. At the steady-state level, transforming growth factor- $\beta 1$ (TGF- $\beta 1$ ) produced in the immune system induces Foxp $3^{+}$regulatory $\mathrm{T}$ cells and maintains self-tolerance (15). However, in the inflammatory insult, by the activated innate immune system IL-6 will suppress the generation of TGF- $\beta 1$-induced Treg cells and induce a pro-inflammatory Th17 cell response (15). $\mathrm{CD} 4{ }^{+} \mathrm{CD} 25^{+}$Tregs play a critical role in maternal tolerance in mice and in humans $(6,9,16)$. $\mathrm{CD} 4{ }^{+} \mathrm{CD} 25^{+}$Tregs play a critical role in PE. This immunological disturbance seems to result from overactivation of the maternal inflammatory response, which involves overproduction of pro-inflammatory cytokines such as interferon- $\gamma$ (IFN- $\gamma$ ), interleukin (IL)-1 $\beta$, IL-6 and tumor necrosis factor- $\alpha$ 
(TNF- $\alpha)$ (14-16) and lower concentrations of regulatory cytokine IL-10 (17,18). Th17 cells are a lineage of CD4 ${ }^{+} \mathrm{T}$ cells that differentiate in the presence of IL- 6 and TGF- $\beta$. These cells express transcription factor retinoic acid-related orphan receptor C (RORc) and produce cytokine IL-17 (19).

Previous researchers found a decrease in Tregs and an increase in Th17-profile cells in the peripheral blood of women with PE compared to normal pregnant women. This imbalance may underlie activation of the inflammatory response in women with PE $(20,21)$.

Tregs are also considered to play a crucial role in the implantation of embryos and the maintenance of maternal immune tolerance to the fetus (22). Zhang et al demonstrated that the percentage of $\mathrm{CD} 4^{+} \mathrm{CD} 25^{+} \mathrm{CD} 127^{-}$cells among the $\mathrm{CD}^{+} \mathrm{T}$ cells was significantly lower in patients with severe PE compared to healthy pregnant women (23). Numerous researchers have sought to establish a protocol for identifying Tregs. Intracellular Foxp3 staining cannot be used to isolate the subpopulation of Tregs for functional tests, as it requires that cells be fixed and permeabilized. Published reports have shown that simultaneous high expression of CD25 and low expression of CD127 correspond with increased expression of intracellular factor Foxp3. This profile allows researchers to identify T cells with suppressor activity $(24,25)$.

A correlation between $\mathrm{CD} 4^{+} \mathrm{CD} 25^{+} \mathrm{CD} 127^{-}$cells and $\mathrm{CD} 4^{+} \mathrm{CD} 25^{+} \mathrm{Foxp}^{+}$cells has been confirmed in healthy individuals (26). No significant difference was found between the number of $\mathrm{CD} 25^{+} \mathrm{CD} 127^{-}$cells among the $\mathrm{CD} 4^{+} \mathrm{T}$ cells with and without permeabilization in the same NHDs (27).

MicroRNAs (miRNAs) are a major class of tissue-specific regulators of gene expression (28). Numerous studies have shown that the miRNAs expressed primarily during pregnancy are clustered in chromosomal regions, suggesting control by the same promoters, and overlap in target genes (29). Many miRNAs have been shown to tightly control placental development, which is a complex physiological process that involves numerous cell types (30). miRNAs are exported from human placental syncytiotrophoblasts into the maternal circulation via exosomes, where they regulate trophoblasT cell invasion, placental immune activation and platelet aggregation $(31,32)$.

Alterations in placental miRNA expression have been associated with in utero exposure and adverse pregnancy outcomes (33-36). Zhao et al (37) reported significantly higher levels of miR-210 in CD4 ${ }^{+} \mathrm{T}$ cells of patients with psoriasis, compared with controls. The same authors confirmed Foxp3 as a target gene regulated by miR-210. After overexpression of miRNA-210, CD4 ${ }^{+} \mathrm{T}$ cells from healthy controls showed decreased expression of Foxp3 and impaired Treg immune suppressor function.

The present study aimed to explore the profile of Th cytokines and Treg/Th17 cells in healthy non-pregnant, normal pregnant and preeclamptic women. The aim of the present study was to characterize the evolution of Treg subsets (defined as $\mathrm{CD} 4^{+} \mathrm{CD} 25^{+}, \mathrm{CD} 4^{+} \mathrm{CD} 25^{+} \mathrm{CD} 127^{-} \mathrm{T}$ cells) in peripheral blood in patients with $\mathrm{PE}$. To investigate the mechanisms underlying Treg/Th17 activity in patients with PE, we also measured mRNA expression of Foxp3, retinoic acid-related orphan receptor $\mathrm{C}(\mathrm{RORc})$ and $\mathrm{miR}-210$ in placenta from patients with PE.

\section{Materials and methods}

A total of 66 women (age, 24-38 years) were included in this study: 29 patients with late-onset preeclampsia ( $\geq 36$ weeks of gestation), 27 pregnant women with normal uncomplicated pregnancies ( $\geq 36$ weeks of gestation) and 10 healthy non-pregnant women. Serum levels of cytokines (IL-6, IL-10, IL-17 and TGF- $\beta 1$ ) were detected using enzyme-linked immunosorbent assay (ELISA). Levels of $\mathrm{CD} 4^{+} \mathrm{CD} 25^{+} \mathrm{CD} 127^{\text {low/- }}$ Tregs in peripheral blood were evaluated by flow cytometry (FCM). The study included 29 patients with PE with placenta as the experimental group and 27 women with normal pregnancy placenta as a control group. Reverse transcription-quantitative polymerase chain reaction (RT-qPCR) was performed to detect mRNA expression of maternal placenta retinoic acid-related orphan receptor $\mathrm{C}$ (RORc), Foxp3 and miR-210. Expression of inflammation-related protein Foxp3 was evaluated by western blot analysis. Samples from the same patient were used to quantify the levels of Tregs, FOX-3 and miR-210.

Study patients. Study participants were enrolled at the Department of Obstetrics and Gynecology, Shenzhen Longhua District Central Hospital (Shenzhen, China). Exclusion criteria were multifetal gestation, hypertension, diabetes, autoimmune or vascular disease, infection (HIV, syphilis or hepatitis B or C) and renal disorder.

Pregnant women were excluded if they had signs of infection. None of the pregnant women were in active labor, and none had rupture of the amniotic membrane. Serum samples were collected at the time of delivery via Cesarean section. Placental tissue was collected during Cesarean section for testing Foxp3, RORc mRNA and miR-210 expression. We also recruited sequential healthy non-pregnant women who were attending routine annual well-woman examinations. None of these women had received hormonal contraception, which may influence peripheral blood lymphocytes (38).

The clinical diagnosis of PE was based on the development of hypertension [blood pressure $(\mathrm{BP}) \geq 140 \times 90 \mathrm{mmHg}$ ] and proteinuria ( $\geq 300 \mathrm{mg} / 24 \mathrm{~h}$ ) during week 20 of gestation or later (39). Late onset PE ( $\geq 34$ weeks) was defined as those patients who displayed gestational hypertension and proteinuria without a history of hypertension.

All women included in the study were recruited during the period from July 2016 to March 2017. The Ethics Committee of the Shenzhen Longhua District Central Hospital approved the study protocol. All patients provided written informed consent prior to the participation in the study.

Measurement of cytokine levels in serum and placenta. Whole blood was collected in sterile EDTA tubes and centrifuged at $3,000 \mathrm{x} \mathrm{g}$ for $15 \mathrm{~min}$ to separate the plasma. Plasma samples were stored at $-80^{\circ} \mathrm{C}$ for subsequent analysis. Cytokine concentrations in plasma were determined by enzyme-linked immunosorbent assay (ELISA). All ELISA kits were purchased from Mlbio Co., Ltd. (Shanghai, China), including: IL-6 (cat. no. m19028583), IL-17 (cat. no. m19028599), IL-10 (cat. no. m19027436) and TGF- $\beta 1$ (cat. no. m16025653). Assay sensitivity limits for IL-6, IL-10, TGF- $\beta 1$ and IL-17 (Th17) were $1.5,1.25,7.5$ and $10 \mathrm{pg} / \mathrm{ml}$, respectively. Absorbance was measured at $450 \mathrm{~nm}$. 
Flow cytometry. EDTA anticoagulated whole blood samples were collected and processed within $24 \mathrm{~h}$. Briefly, peripheral blood mononuclear cells (PBMCs) were obtained with standard Ficoll-Hypaque technique. PBMCs $\left(5 \times 10^{5}\right)$ were stained with the following antibodies: Fluorescein isothiocyanate-conjugated CD127 (cat. no. 560549; BD Pharmingen; BD Biosciences, San Jose, CA, USA); phycoerythrin-conjugated CD25 (cat. no. 557138; BD Pharmingen; BD Biosciences) and allophycocyanin-conjugated CD4 (cat. no. 551980; BD Pharmingen; BD Biosciences) at $4^{\circ} \mathrm{C}$ in dark for $30 \mathrm{~min}$. Following washing with FACs buffer (PBS with $2 \%$ fetal bovine serum (FBS, cat. no. 10099141; Thermo Fisher Scientific, Inc., Waltham, MA, USA) and 1 mM EDTA), cells were analyzed using a BD FACSAria II cell sorter with BD FACSDiva software (Version 6.1; BD Biosciences); a subpopulation of $\mathrm{CD} 4^{+} \mathrm{CD} 25^{+} \mathrm{CD} 127^{-}$cells was identified.

mRNA expression of Foxp3 and RORc. Placentas from a total of 56 women were included in this study. The women consented to the collection of samples at the time of birth. A full-thickness placental biopsy was obtained after delivery, avoiding the periphery and areas of obvious infarction. Samples obtained were flash frozen in liquid nitrogen and stored at $-80^{\circ} \mathrm{C}$ prior to analysis. RT-qPCR was performed to measure mRNA expression of ROR, Foxp3 and miR-210 in maternal placenta.

mRNA expression levels of transcription factors associated with Treg/Th17 in placenta were measured by RT-qPCR. miRNA was extracted from 30-50 mg fresh tissue with the Qiagen miRNeasy Mini kit (cat. no. 217004; Qiagen GmbH, Hilden, Germany). Total RNA was extracted from 30-50 mg fresh tissue using TRIzol ${ }^{\circledR}$ Reagent (cat. no. 15596026; Invitrogen; Thermo Fisher Scientific, Inc., Waltham, MA, USA) according to the manufacturer's instructions. cDNA was synthesized with PrimeScript RT Master Mix (Takara Bio, Inc., Shiga, Japan), as described in the manufacturer's instructions. qPCR was performed with PowerUp SYBR Green Master Mix (cat. no. a25780; Thermo Fisher Scientific, Inc.). Table II shows all PCR primer pairs. qPCR was carried out in duplicate wells using a LightCycler Real-Time PCR System (Roche Diagnostics, Indianapolis, IN, USA). Quantitation cycle (Cq) values for target genes and the housekeeping gene GAPDH were calculated. Levels of mRNA and miRNA expression were normalized to GAPDH and U6 respectively, and relative expression of indicated genes in PE were compared to that in normal pregnant women using the $2^{-\Delta \Delta \mathrm{Cq}}$ method (40).

Western blotting of Foxp3. For protein extraction, 30-50 mg placentas were homogenized, washed with PBS, and lysed for $30 \mathrm{~min}$ in ice-cold radioimmunoprecipitation assay lysis buffer supplemented with $10 \mathrm{mM} \mathrm{NaF}, 1 \mathrm{mM} \mathrm{Na} \mathrm{VO}_{4}, 1 \mathrm{mM}$ phenylmethylsulfonyl fluoride and protease inhibitor cocktail (Sigma-Aldrich; Merck KGaA, Darmstadt, Germany). Protein concentrations were determined by Pierce BCA Protein Assay kit, according to the manufacturer's instructions (cat. no. 23225; Thermo Fisher Scientific, Inc.). Proteins samples $(\sim 30 \mu \mathrm{g})$ were separated by $10 \%$ SDS-PAGE and electrotransferred to polyvinylidene fluoride (PVDF) membranes (EMD Millipore, Billerica, MA, USA). PVDF membranes were blocked using $5 \%$ non-fat dried milk dissolved in TBS (20 mM Tris- $\mathrm{HCl}$,
$150 \mathrm{mM} \mathrm{NaCl}, \mathrm{pH}$ 7.6) supplemented with $0.1 \%$ (v/v) Tween-20 (TBST) at room temperature for $1 \mathrm{~h}$. Following washing with TBST, the PVDF membranes were incubated with 1:500 diluted anti-FOXP3 antibody (cat. no. ab4728; Abcam, Cambridge, MA, USA) overnight at $4^{\circ} \mathrm{C}$. Membranes were washed with TBST and subsequently incubated with horseradish peroxidase (HRP)-conjugated goat anti-rabbit antibody (1:5,000; cat. no. ab205718; Abcam) for $1 \mathrm{~h}$ at room temperature; protein bands were visualized with the Enhanced Chemiluminescence (ECL) detection reagents (Millipore). Membranes were then stripped and reblotted with 1:5,000 diluted anti- $\beta$-actin antibody (cat. no. A5316; Sigma-Aldrich; Merck KGaA) at room temperature for $1 \mathrm{~h}$. Following TBST washing, blots were incubated with HRP-conjugated goat anti-mouse secondary antibody (1:5,000; cat. no. ab205719; Abcam) for $1 \mathrm{~h}$ at room temperature; the blots were visualized with the ECL detection reagents. Protein expression levels were calculated as the relative band density to that of $\beta$-actin using ImageJ software (National Institute of Health, Bethesda, MD, USA).

Statistical analysis. Continuous variables are presented as mean \pm standard deviation. For continuous variables, inter-group differences were compared with Student's t-test (for 2 groups) or one-way analysis of variance (ANOVA; for $\geq 3$ groups). For significant differences in ANOVA, multiple comparisons were conducted with the Dunnett's t-test. For categorical variables, inter-group differences were compared with the $\chi^{2}$ test or the Fisher's exact probability test. $\mathrm{P}<0.05$ was considered to indicate a statistically significant difference.

\section{Results}

Patient characteristics. The clinical characteristics of the study participants are presented in Table I. The percentage of primiparas was similar in all study groups. Maternal age was significantly higher among preeclamptic patients compared with normal pregnant women. Gestational age was significantly lower in preeclamptic patients than in normal pregnant women. Systolic and diastolic blood pressures were significantly higher in both preeclamptic groups as compared to normal pregnant women. All other clinical features presented in Table I differed significantly among groups. Fetal growth restriction was absent in normal pregnant women but observed in $41.4 \%$ of preeclamptic women.

Cytokine levels. Regulatory T cells are well known to suppress effector activity of $\mathrm{T}$ cells. We then aimed to determine cytokine production in the patients with PE. Plasma production of IL-6, IL-17 and TGF- $\beta 1$ was significantly higher in preeclamptic patients compared with these levels in normal pregnant women $(\mathrm{P}=0.0021, \mathrm{P}=0.015$ and $\mathrm{P}=0.019$, respectively; Fig. 1A-C). Accordingly, levels of Treg cytokines such as IL-10 were significantly lower in preeclamptic women than in normal pregnant women ( $\mathrm{P}=0.0012$; Fig. 1D). Levels of serum IL-17, TGF- $\beta 1$ and IL-10 were similar in healthy non-pregnant and normal pregnant women $(\mathrm{P}=0.085, \mathrm{P}=0.163$ and $\mathrm{P}=0.248$, respectively; Fig. 1B-D). However, levels of serum IL-6 were significantly higher in healthy non-pregnant women than in normal pregnant women ( $\mathrm{P}=0.008$; Fig. $1 \mathrm{~A})$. 
Table I. Clinicopathological characteristics of the patients used in the present study.

\begin{tabular}{|c|c|c|c|c|}
\hline $\begin{array}{l}\text { Clinicopathological } \\
\text { characteristic }\end{array}$ & $\begin{array}{c}\text { Patients with } \\
\text { preeclampsia }(n=29)\end{array}$ & $\begin{array}{l}\text { Normal pregnant } \\
\text { women }(n=27)\end{array}$ & $\begin{array}{l}\text { Healthy non-pregnant } \\
\text { women }(\mathrm{n}=10)\end{array}$ & $\begin{array}{c}\text { ANOVA } \\
\text { F value; P-value }\end{array}$ \\
\hline Maternal age at delivery (years) & $31 \pm 7^{\mathrm{a}, \mathrm{b}}$ & $26 \pm 6$ & $27 \pm 7$ & $4.251 ; 0.015$ \\
\hline BMI at blood draw $\left(\mathrm{kg} / \mathrm{m}^{2}\right)$ & $28.7 \pm 6.3^{\mathrm{a}, \mathrm{b}}$ & $26.0 \pm 5.9^{\mathrm{b}}$ & $21.6 \pm 1.6$ & $4.912 ; 0.001$ \\
\hline Gestational age at delivery (weeks) & $37 \pm 2.1^{\mathrm{a}}$ & $39 \pm 2.2$ & n.a. & $2.376 ;<0.001$ \\
\hline Primiparous women $(\%)$ & $17(58.6 \%)$ & $16(59.25 \%)$ & n.a. & $0.002 ; 0.961$ \\
\hline Systolic blood pressure (mmHg) & $155 \pm 49^{\mathrm{a}, \mathrm{b}}$ & $119 \pm 30$ & $115 \pm 36$ & $6.814 ; 0.001$ \\
\hline Diastolic blood pressure (mmHg) & $100 \pm 36^{\mathrm{a}, \mathrm{b}}$ & $77 \pm 26$ & $74 \pm 33$ & $4.593 ; 0.010$ \\
\hline Fetal birth weight (g) & $2,932 \pm 378^{c}$ & $3,212 \pm 212$ & n.a. & $2.563 ; 0.013$ \\
\hline Fetal growth restriction (\%) & $12(41.4 \%)^{\mathrm{a}}$ & 0 & n.a. & $<0.001$ \\
\hline
\end{tabular}

${ }^{\mathrm{a}} \mathrm{P}<0.001$ vs. normal pregnant women; ${ }^{\mathrm{b}} \mathrm{P}<0.001 \mathrm{vs}$. healthy non-pregnant women; ${ }^{\mathrm{c}} \mathrm{P}<0.05$ vs. normal pregnant women. Data are presented as the mean \pm standard deviation for continuous variables and as number (percentage) for categorical variables. ANOVA, analysis of variance; BMI, body mass index; n.a., not applicable.

Table II. Primer sequences used for RT-qPCR.

\begin{tabular}{ll}
\hline Gene & \multicolumn{1}{c}{ qPCR primer sequence $\left(5^{\prime} \rightarrow 3^{\prime}\right)$} \\
\hline Foxp3 & F: GTGGCCCGGATGTGAGAAG \\
& R: GGAGCCCTTGTCGGATGATG \\
RORc & F: GAAGTGGTGCTGGTTAGGATGTG \\
& R: GCCACCGTATTTGCCTTCAA \\
GAPDH & F: GCACCGTCAA-GGCTGAGAAC \\
& R: TGGTGAAGACGCCAGTGGA \\
U6 & F: TGCGGGTGCTCGCTTCGGCAGC \\
& R: CCAGTGCAGGGTCCGAGGTAT \\
miR-210 & F: CGGCGGTCTGTGCGTGTGACAGC \\
& R: CCAGTGCAGGGTCCGAGGTAT \\
\hline
\end{tabular}

Gene

RT primer sequence $\left(5^{\prime} \rightarrow 3^{\prime}\right)$

U6 RT

miR-210 RT

GTCGTATCCAGTGCAGGGTCCGAGG
TATTCGCACTGGATACGACAAAATAT
GGAAC
GTCGTATCCAGTGCAGGGTCCGAGG TATTCGCACTGGATACGACTCAGCC

F, forward; Foxp3, forkhead box p3; miR, microRNA; qPCR, quantitative polymerase chain reaction; $\mathrm{R}$, reverse; RORc, retinoic acid-related orphan receptor C; RT, reverse transcription.

Decreased frequency of Tregs in preeclampsia patient. Tregs are key players in successful pregnancy and their deficiencies are implicated in complications in pregnancy such as PE, but the results are inconsistent among studies. Although the percentage of $\mathrm{CD}^{+} \mathrm{CD} 25^{+}$cells among the $\mathrm{CD} 4^{+} \mathrm{T}$ cells was notably higher in the normal pregnancy group compared to the percentage in the healthy non-pregnant women $(46.27 \pm 1.11 \mathrm{vs}$. $42.71 \pm 1.05 \%$ ), the difference was not significant; the percentage of $\mathrm{CD} 4^{+} \mathrm{CD} 25^{+}$cells among the $\mathrm{CD} 4^{+} \mathrm{T}$ cells were significantly lower in women with PE compared with normal pregnant subjects and healthy non-pregnant subjects (both $\mathrm{P}<0.01$; Fig. 2A). The percentage of $\mathrm{CD} 4^{+} \mathrm{CD} 25^{+} \mathrm{CD} 127^{-}$cells among the $\mathrm{CD}^{+} \mathrm{T}$ cells was analyzed in peripheral blood of patients, and the percentage of $\mathrm{CD} 4^{+} \mathrm{CD} 25^{+} \mathrm{CD} 127^{-}$cells among the $\mathrm{CD}^{+} \mathrm{T}$ cells was significantly lower in the peripheral blood of patients with PE compared with normal pregnant women (6.34 \pm 0.28 vs. $9.10 \pm 0.28 \%$; $\mathrm{P}<0.01$; Fig. $2 \mathrm{~B})$. The percentage of $\mathrm{CD}^{+} \mathrm{CD} 25^{+} \mathrm{CD} 127^{-}$cells among the $\mathrm{CD} 4^{+} \mathrm{T}$ cells was significantly lower in the peripheral blood of PE compared with healthy non-pregnant women $(6.34 \pm 0.28$ vs. $8.75 \pm 0.54 \%$; $\mathrm{P}<0.01)$. However, the proportion of $\mathrm{CD} 4^{+} \mathrm{CD} 25^{+} \mathrm{CD} 127^{-}$cells among the $\mathrm{CD}^{+} \mathrm{T}$ cells was similar in healthy non-pregnant and normal pregnant women, indicating that a decrease in $\mathrm{CD} 4{ }^{+} \mathrm{CD} 25^{+} \mathrm{CD} 127^{-}$cells was associated with PE. These findings suggest that the proportion of Tregs in peripheral blood was increased in normal pregnant subjects but decreased in women with PE. The number of $\mathrm{CD} 4^{+} \mathrm{CD} 25^{+} \mathrm{CD} 127^{-} \mathrm{T}$ cell population decreased in peripheral blood of $\mathrm{PE}$ patients. The image shows the typical data of the $\mathrm{T}$ cell through flow cytometry (Fig. 3). The peripheral blood of patients with PE exhibited a decline in the population of $\mathrm{CD} 4{ }^{+} \mathrm{CD} 25^{+} \mathrm{T}$ cells; typical $\mathrm{T}$ cell data from flow cytometry are presented in Fig. 4.

Expression of Foxp3, RORc and miR-210 in placenta. The mRNA expression levels of transcription factors associated with Treg/Th17 cells were analyzed in placentas from patients with PE and normal pregnant women. miR-210 was previously reported to target Foxp3 and inhibit Treg cell function in patients with psoriasis (37). In the present study, significantly higher expression of miR-210 was observed in patients with PE compared with normal pregnant women $(1.744 \pm 0.153$ vs. $0.578 \pm 0.744$; $\mathrm{P}<0.01$; Fig. $5 \mathrm{~A})$. In addition, mRNA expression levels of RORc were significantly higher in women with PE compared with normal pregnant women $(0.599 \pm 0.069$ vs. $0.380 \pm 0.046 ; \mathrm{P}=0.0127$; Fig. $5 \mathrm{~B}$ ). Higher expression of RORc may promote enhanced production on inflammatory cytokines (20). The results demonstrated that mRNA expression of Foxp3 was significantly lower in preeclamptic women compared with normal pregnant women $(0.713 \pm 0.088$ vs. 

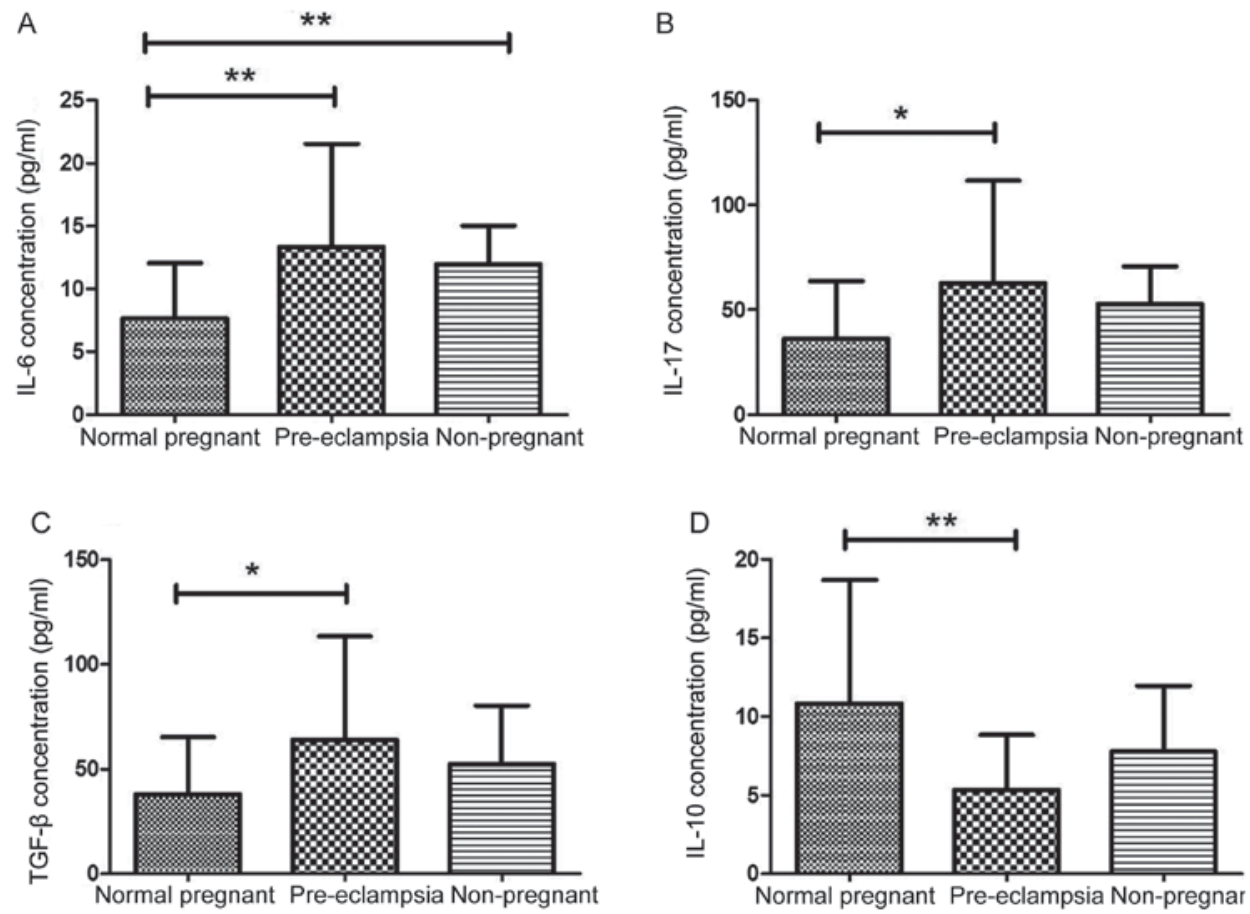

Figure 1. Expression of pro-inflammatory cytokines were varied in plasma of patients with PE. (A-D) Concentrations of (A) IL-6, (B) IL-17, (C) TGF- $\beta 1$ and (D) IL-10 were determined by ELISA in the plasma of normal pregnant women $(n=27)$, patients with PE $(n=29)$ and non-pregnant women $(n=10)$. Levels of pro-inflammatory cytokines (A) IL-6, (B) IL-17 and (C) TGF- $\beta 1$ were significantly higher in women with PE compared with normal pregnant women. Levels of regulatory T cell cytokine IL-10 were significantly lower in preeclamptic women compared with normal pregnant women Results are expressed as the mean \pm standard deviation; " $\mathrm{P}<0.05,{ }^{*} \mathrm{P}<0.01$. IL, interleukin; PE, preeclampsia; TGF- $\beta 1$, transforming growth factor- $\beta 1$.
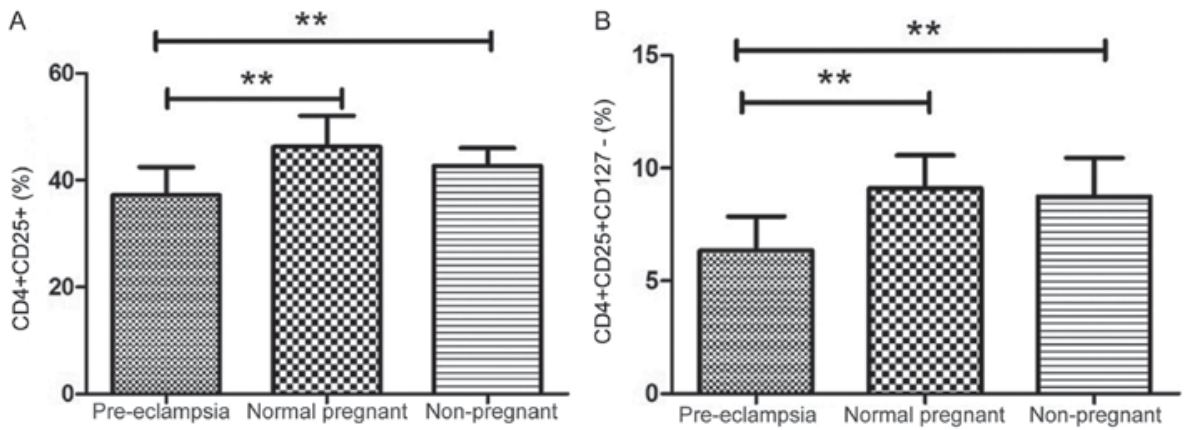

Figure 2. Different frequencies of $\mathrm{CD} 4{ }^{+} \mathrm{CD} 25^{+} \mathrm{CD} 127^{-}$and $\mathrm{CD} 4{ }^{+} \mathrm{CD} 25^{+} \mathrm{T}$ cells in patients with $\mathrm{PE}$, normal pregnant women and non-pregnant women (A) Representative results of flow cytometric analysis for $\mathrm{CD} 4^{+} \mathrm{CD} 25^{+} \mathrm{CD} 127^{-}$cells among the $\mathrm{CD} 4^{+} \mathrm{T}$ cell population. (B) Relative proportion of $\mathrm{CD} 4^{+} \mathrm{CD} 25^{+}$ $\mathrm{T}$ cells among the $\mathrm{CD} 4^{+} \mathrm{T}$ cells. Values are presented as the mean \pm standard deviation; ${ }^{* *} \mathrm{P}<0.01$. PE, preeclampsia.

1.105 \pm 0.136 ; $\mathrm{P}=0.019$; Fig. 5C), which was consistent with decreased Tregs in patients with PE.

Expression of inflammation-related protein Foxp3. Consistent with mRNA expression results, lower protein expression levels of Foxp3 was observed in patients with PE compared with normal pregnant subjects; however, this difference was not indicated to be significant (Fig. 6).

\section{Discussion}

Foxp3 is a member of the fork head transcription factor family and is exclusively expressed in $\mathrm{CD} 4{ }^{+} \mathrm{CD} 25^{+}$ Tregs (41). CD $4{ }^{+} \mathrm{CD} 25^{+}$Tregs are a subset of mature $\mathrm{T}$ cells that play an important role in maintaining immune homeostasis and preventing autoimmune disease. Patients with preeclampsia (PE) have been shown to have fewer active $\mathrm{CD} 4{ }^{+} \mathrm{CD} 25^{+}$Tregs in peripheral blood and related tissues (42).

The TGF- $\beta 1$ signaling pathway is involved in the induction of Foxp3 as well as the generation of peripheral $\mathrm{T}$ cells and thymocytes. Previous research has revealed a reduced number of $\mathrm{CD} 4^{+} \mathrm{CD} 25^{+} \mathrm{Foxp}^{+}$Tregs in the peripheral blood of women with PE compared to normal pregnant women. $\mathrm{CD} 4^{+} \mathrm{CD} 25^{+} \mathrm{Foxp}^{+}$Tregs express specific anti-inflammatory cytokines such as IL-10, which dampen an excessive effector immune response $(43,44)$.

In the absence of any inflammatory insult, TGF- $\beta$ produced in the immune system will suppress the generation of effector T cells and induce Foxp $3^{+}$Tregs, thus, maintaining self-tolerance. However, upon infection or inflammation, IL- 6 produced by the activated innate immune system will 
Pre-eclampsia

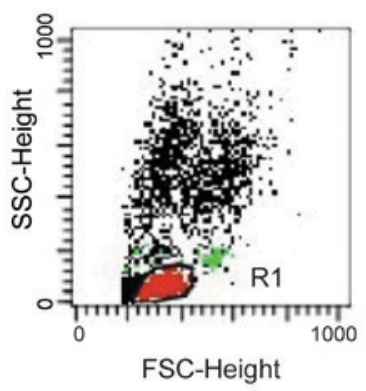

Normal pregnant

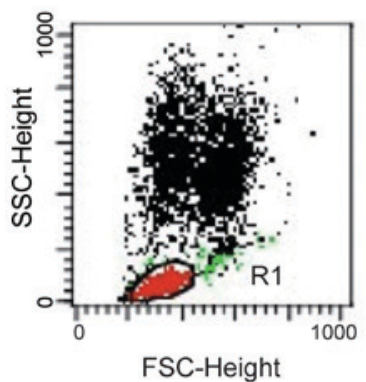

Non-pregnant

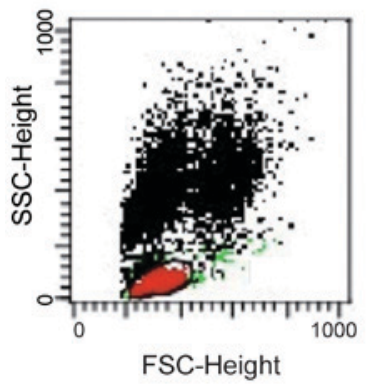

CD4+CD25+CD127- (5.53\%)
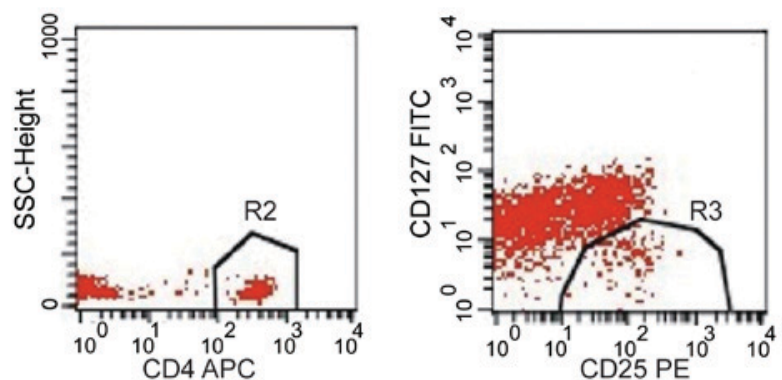

CD4+CD25+CD127- $(9.25 \%)$
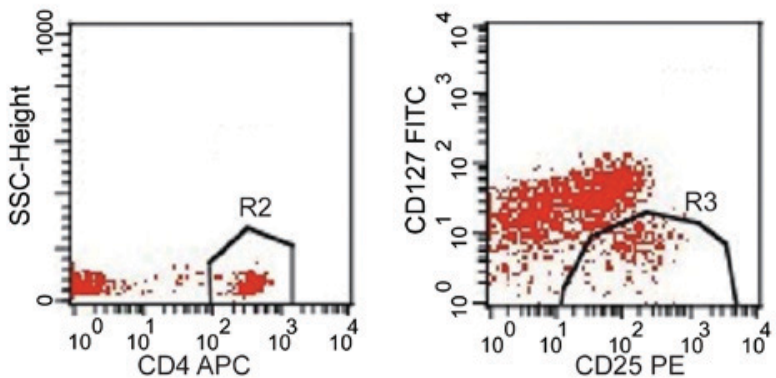

CD4+CD25+CD127- (8.89\%)
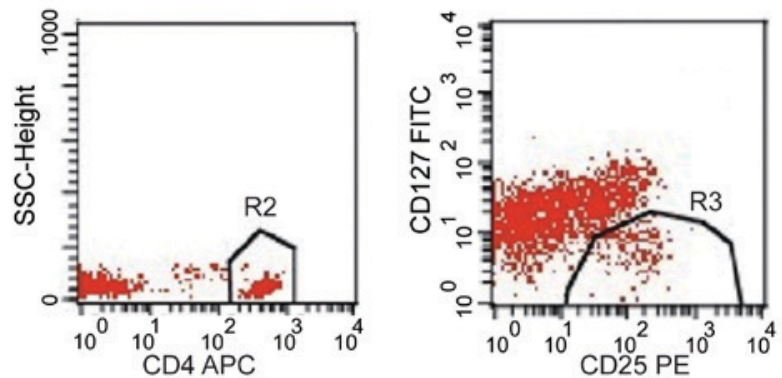

Figure 3. $\mathrm{CD}^{+} \mathrm{CD} 25^{+} \mathrm{CD} 127^{-} \mathrm{T}$ cell population is decreased in peripheral blood of patients with PE. Peripheral blood mononuclear cells were purified from normal pregnant women, pregnant women with PE and non-pregnant women and stained for CD4, CD25 and CD127. Images show representative flow cytometry data for total T cells. Plots are gated on CD4+ lymphocytes. APC, allophycocyanin; FITC, fluorescein isothiocyanate; FSC, forward scatter; $\mathrm{PE}$, phycoerythrin; PE, preeclampsia; SSC, side scatter.

suppress the generation of TGF- $\beta$-induced Tregs and induce a pro-inflammatory $\mathrm{T}$-cell response (predominately Th17 cells) (45). These results support the results of recent studies showing an increase in circulating levels of IL-17 in pregnant women with PE when compared to healthy pregnant women and non-pregnant women (46).

The results obtained for healthy non-pregnant women in this study are consistent with those of previous studies, which report a higher prevalence of peripheral blood IL-17 in preeclamptic patients $(21,47,48)$. TGF- $\beta 1$ may act as a potent inhibitor of $\mathrm{T} / \mathrm{B}$ cell proliferation and auto-antibody production (49). TGF- $\beta 1$ also contributes to suppression of the $\mathrm{T}$ cell response by regulating Foxp $3^{+}$Tregs and is essential to the development of natural Tregs (nTregs) and induced Tregs (iTregs) (50). nTregs are produced in the thymus early in life, and iTregs are generated in the periphery from naive $\mathrm{CD}^{+}$ $\mathrm{T}$ cells (51). Tregs maintain peripheral tolerance through both cell-contact-dependent and cell-contact-independent mechanisms (52).

In the present study, we measured serum levels of cytokines (IL-6, IL -10, IL-17 and TGF- $\beta 1$ ) in healthy non-pregnant women, normal pregnant women and preeclamptic patients. The results showed that serum IL-17, IL-6 and TGF- $\beta 1$ levels were significantly higher in preeclamptic patients than in normal pregnant women. Levels of Treg cytokines IL-10 were significantly lower in preeclamptic women than in normotensive women.

To further investigate the mechanisms resulting in deficient Tregs in PE, we measured mRNA expression levels of transcription factors that play an important role in the proliferation and differentiation of Tregs in PE. Foxp3 is known as a specific molecular marker for Tregs and is indispensable to the development and function of Tregs (53).

In the present study, the authors suggest that peripheral $\mathrm{CD} 4{ }^{+} \mathrm{CD} 25^{+}$Tregs cannot be accurately identified and purified based on surface expression of CD127 (as an alternative to expression of transcription factor Foxp3) (54). Therefore, low expression of the CD127 molecule is not an inherent attribute of Tregs (55).

In the present study, cytofluorometry showed that the percentage of $\mathrm{CD}^{+} \mathrm{CD} 25^{+} \mathrm{CD} 127^{-}$Tregs among $\mathrm{CD} 4^{+} \mathrm{T}$ cells in peripheral blood was reduced in patients with $\mathrm{PE}$ compared 


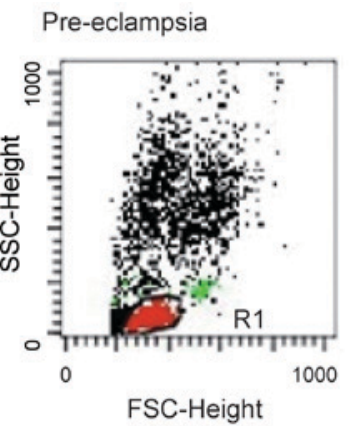

Normal pregnant

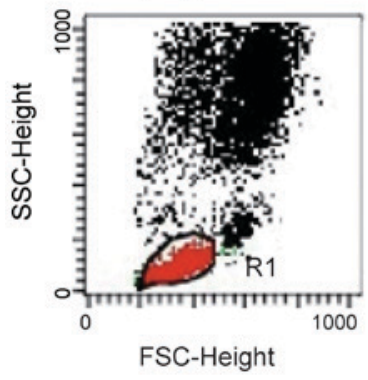

Non-pregnant

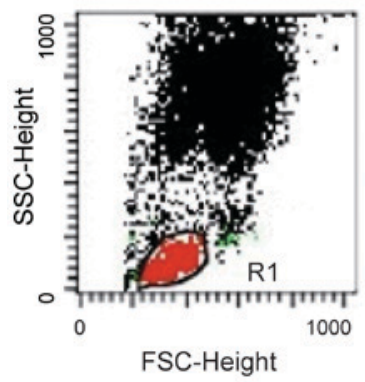

CD4+CD25+(29.48\%)
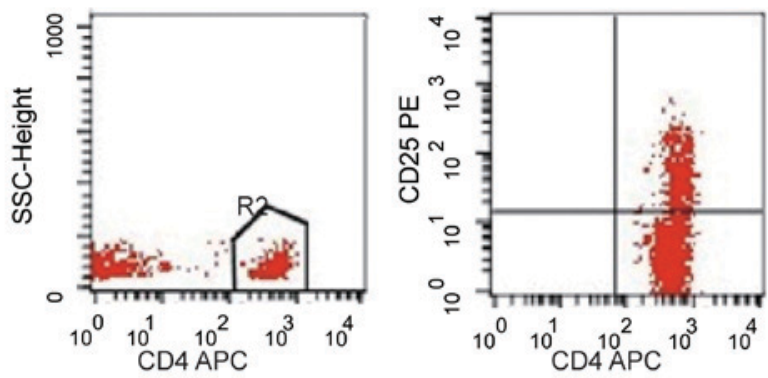

CD4+CD25+ (46.95\%)
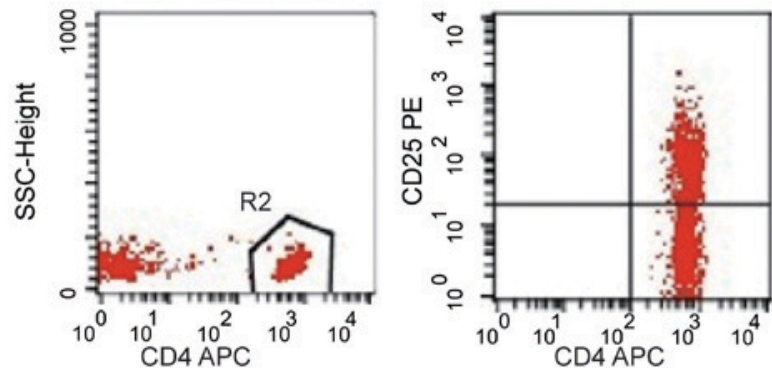

CD4+CD25+ (38.19\%)
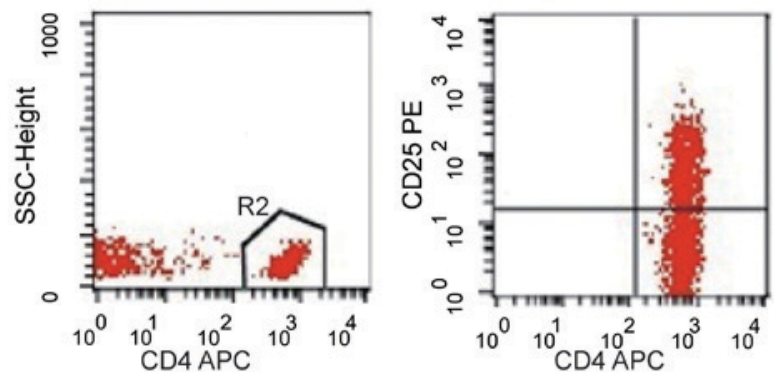

Figure 4. Decreased number of $\mathrm{CD} 4^{+} \mathrm{CD} 25^{+} \mathrm{T}$ cell population in peripheral blood of patients with preeclampsia. Images show representative data by flow cytometry for total $\mathrm{T}$ cells stained for CD4 and CD25. Plots are gated on CD4+ lymphocytes. FSC, forward scatter; SSC, side scatter.
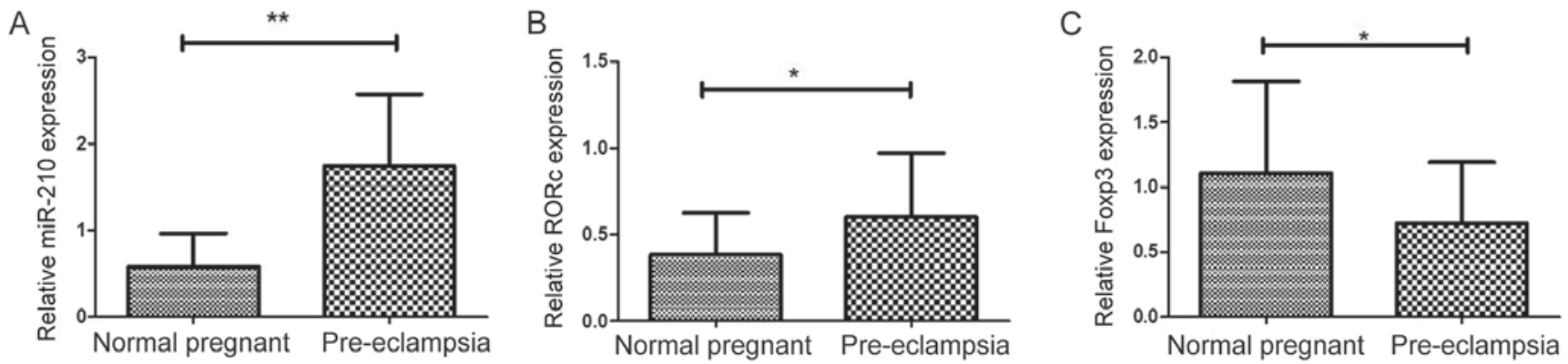

Figure 5. Expression levels of miR-210, RORc and Foxp3 in placenta. (A-C) Expression levels of (A) miR-210, (B) RORc and (C) Foxp3 in placenta attachment deciduas obtained from pregnant women with preeclampsia $(n=29)$ and normal pregnant women $(n=27)$ were analyzed by reverse transcription-quantitative polymerase chain reaction. Results are expressed as the mean \pm standard deviation; ${ }^{*} \mathrm{P}<0.05$ and ${ }^{* *} \mathrm{P}<0.01$. Foxp3, forkhead box $\mathrm{p}$; miR, microRNA; RORc, retinoic acid-related orphan receptor C.

to normal pregnant women and healthy non-pregnant women. Furthermore, the percentage of $\mathrm{CD} 4{ }^{+} \mathrm{CD} 25^{+}$Tregs was significantly lower in the peripheral blood of patients with $\mathrm{PE}$ compared to normal individuals.

Such tissue-specific patterns of gene expression are regulated by miRNAs. In this study, the mRNA expression of Foxp3 was significantly lower in placenta from patients with PE. The mRNA expression of miR-210 showed a significant increase in PE. Furthermore, protein levels of Foxp3 were notably decreased in patients with PE, compared to normal pregnant subjects. These differences in miRNA expression are important as miRNAs (non-coding RNAs approximately 19-25 nucleotides in length) regulate nearly 30-50\% of all genes by binding to target protein-encoding mRNAs.

In conclusion, the results from our experiments demonstrated that serum IL-10 levels are decreased in women with 

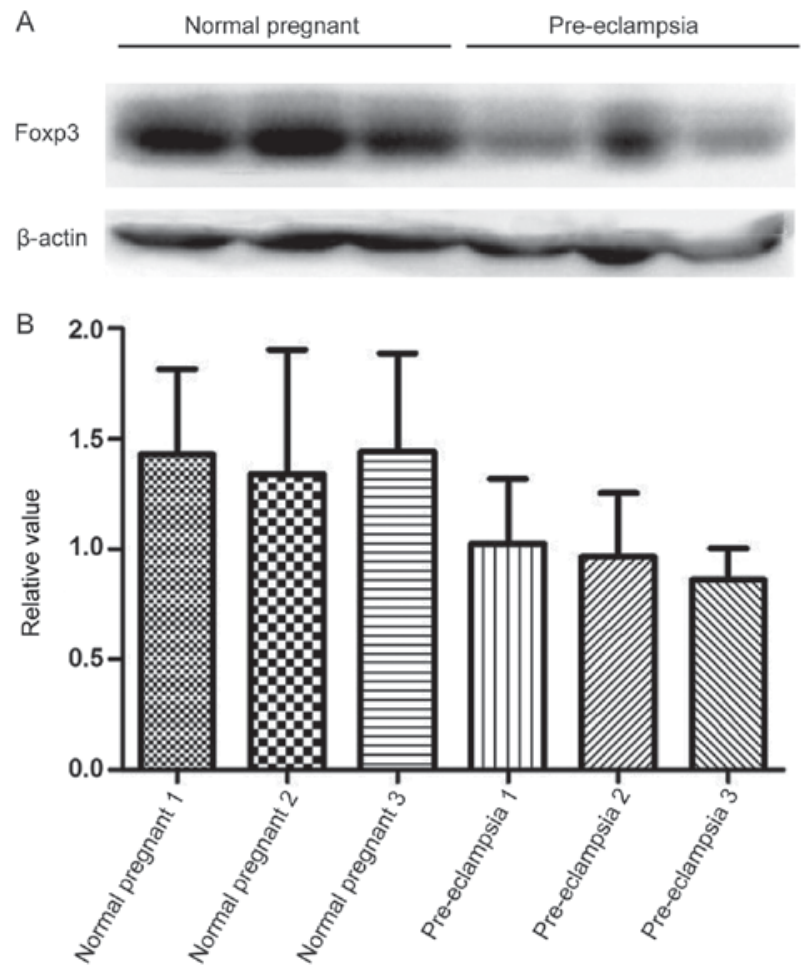

Figure 6. Protein expression levels of Foxp3 in placenta. (A) Protein expression levels of Foxp3 in placenta attachment deciduas of pregnant women with preeclampsia and normal pregnant women were detected by western blot analysis. (B) Statistical analysis of relative protein expression in (A) Foxp3, forkhead box p3.

PE. This effect may contribute to the development of excessive systemic inflammation, as is characteristic of maternal PE. The findings presented above show a decreased number of circulating $\mathrm{CD}^{+} \mathrm{CD} 25^{+} \mathrm{CD} 127^{-}$Tregs in women with PE compared with normal pregnant women. Placenta from patients with $\mathrm{PE}$ showed significantly decreased mRNA expression of Foxp3 and significantly increased expression of miR-210. The existence of a positive correlation between expression of miR-210 and Foxp3 protein in PE requires further experimental verification. Additional studies are required to confirm and extend these findings.

\section{Acknowledgements}

Not applicable.

\section{Funding}

The present study was supported by grants from The 2016 Shenzhen Science and Technology R\&D Fundamental Research: Medical and Health Free Exploration (grant no. JCYJ20160428140315277) and The 2016 Shenzhen Municipal Health and Family Planning Commission (grant no. 201606027).

\section{Availability of data and materials}

The data sets used and/or analysed during the current study are available from the corresponding author on reasonable request.

\section{Authors' contributions}

JC designed the experiments and wrote the initial draft of the manuscript. LZ, DW, YX, HG and WT conducted the experiments and analyzed the data. CW analyzed and interpreted the data, and drafted the manuscript.

\section{Ethics approval and consent to participate}

All experimental research on human samples followed the guidelines and approvals of Shenzhen Longhua District Central Hospital Ethics Committee (Shenzhen, China). The Ethics Committee of the Shenzhen Longhua District Central Hospital approved the study protocol. All patients provided written informed consent prior to the participation in the study.

\section{Patient consent for publication}

Not applicable.

\section{Competing interests}

The authors declare that they have no competing interest.

\section{References}

1. Abalos E, Cuesta C, Grosso AL, Chou D and Say L: Global and regional estimates of preeclampsia and eclampsia: A systematic review. Eur J Obstet Gynecol Repro Biol 170: 1-7, 2013.

2. Moore-Maxwell CA and Robboy SJ: Placental site trophoblastic tumor arising from antecedent molar pregnancy. Gynecol Oncol 92: 708-712, 2004.

3. Ilekis JV, Reddy UM and Roberts JM: Preeclampsia-A pressing problem: An executive summary of a national institute of child health and human development workshop. Reprod Sci 14: 508-523, 2007.

4. Lok CA, Jebbink J, Nieuwland R, Faas MM, Boer K, Sturk A and Van Der Post JA: Leukocyte activation and circulating leukocyte-derived microparticles in preeclampsia. Am J Reprod Immunol 61: 346-359, 2009.

5. Sakaguchi S, Sakaguchi N, Asano M, Itoh M and Toda M: Immunologic self-tolerance maintained by activated $T$ cells expressing IL-2 receptor alpha-chains (CD25). Breakdown of a single mechanism of self-tolerance causes various autoimmune diseases. J Immunol 155: 1151-1164, 1995.

6. Aluvihare VR, Kallikourdis M and Betz AG: Regulatory T cells mediate maternal tolerance to the fetus. Nat Immuno 5: 266-271, 2004.

7. Xiong YH, Yuan $\mathrm{Z}$ and $\mathrm{He} \mathrm{L}$ : Effects of estrogen on $\mathrm{CD} 4^{+} \mathrm{CD} 25^{+}$ regulatory $\mathrm{T}$ cell in peripheral blood during pregnancy. Asian Pac J Trop Med 6: 748-752, 2013.

8. Heikkinen J, Mottonen M, Alanen A and Lassila O: Phenotypic characterization of regulatory $\mathrm{T}$ cells in the human decidua. Clin Exp Immunol 136: 373-378, 2004.

9. Zenclussen AC, Gerlof K, Zenclussen ML, Sollwedel A, Bertoja AZ, Ritter T, Kotsch K, Leber J and Volk HD: Abnormal T-cell reactivity against paternal antigens in spontaneous abortion: Adoptive transfer of pregnancy-induced $\mathrm{CD} 4{ }^{+} \mathrm{CD} 25^{+}$ $\mathrm{T}$ regulatory cells prevents fetal rejection in a murine abortion model. Am J Pathol 166: 811-822, 2005.

10. Sasaki Y, Darmochwal-Kolarz D, Suzuki D, Sakai M, Ito M, Shima T, Shiozaki A, Rolinski J and Saito S: Proportion of peripheral blood and decidual $\mathrm{CD} 4{ }^{+} \mathrm{CD} 25^{\text {bright }}$ regulatory $\mathrm{T}$ cells in pre-eclampsia. Clin Exp Immunol 149: 139-145, 2007.

11. Darmochwal-Kolarz D, Saito S, Rolinski J, Tabarkiewicz J, Kolarz B, Leszczynska-Gorzelak B and Oleszczuk J: Activated $\mathrm{T}$ lymphocytes in pre-eclampsia. Am J Reprod Immunol 58: 39-45, 2007.

12. Nakashima A, Shima T, Inada K, Ito $M$ and Saito $S$ : The balance of the immune system between T cells and NK cells in miscarriage. Am J Reprod Immunol 67: 304-310, 2012. 
13. Koucky M, Malickova K, Cindrova-Davies T, Germanova A, Parizek A, Kalousova M, Hajek Z and Zima T: Low levels of circulating T-regulatory lymphocytes and short cervical length are associated with preterm labor. J Reprod Immunol 106: 110-117, 2014.

14. Xiong $\mathrm{H}$, Zhou $\mathrm{C}$ and Qi G: Proportional changes of $\mathrm{CD} 4^{+} \mathrm{CD} 25^{+} \mathrm{Foxp}^{+}$regulatory $\mathrm{T}$ cells in maternal peripheral blood during pregnancy and labor at term and preterm. Clin Invest Med 33: E422, 2010.

15. Sakaguchi S, Ono M, Setoguchi R, Yagi H, Hori S, Fehervari Z, Shimizu J, Takahashi T and Nomura T: Foxp $3^{+} \mathrm{CD} 25^{+} \mathrm{CD} 4^{+}$ natural regulatory $\mathrm{T}$ cells in dominant self-tolerance and autoimmune disease. Immunol Rev 212: 8-27, 2006.

16. Sasaki Y, Sakai M, Miyazaki S, Higuma S, Shiozaki A and Saito S: Decidual and peripheral blood $\mathrm{CD} 4{ }^{+} \mathrm{CD} 25^{+}$regulatory $\mathrm{T}$ cells in early pregnancy subjects and spontaneous abortion cases. Mol Hum Reprod 10: 347-353, 2004.

17. Cristofalo R, Bannwart-Castro CF, Magalhaes CG, Borges VT, Peracoli JC, Witkin SS and Peracoli MT: Silibinin attenuates oxidative metabolism and cytokine production by monocytes from preeclamptic women. Free Radic Res 47: 268-275, 2013.

18. Peracoli JC, Bannwart-Castro CF, Romao M, Weel IC, Ribeiro VR, Borges VT, Rudge MV, Witkin SS and Peracoli MT: High levels of heat shock protein 70 are associated with pro-inflammatory cytokines and may differentiate early- from late-onset preeclampsia. J Reprod Immunol 100: 129-134, 2013.

19. Figueiredo AS and Schumacher A: The T helper type 17/regulatory T cell paradigm in pregnancy. Immunology 148: 13-21, 2016.

20. Darmochwal-Kolarz D, Kludka-Sternik M, Tabarkiewicz J, Kolarz B, Rolinski J, Leszczynska-Gorzelak B and Oleszczuk J: The predominance of Th17 lymphocytes and decreased number and function of Treg cells in preeclampsia. J Reprod Immunol 93: 75-81, 2012.

21. Santner-Nanan B, Peek MJ, Khanam R, Richarts L, Zhu E, Fazekas de St Groth B and Nanan R: Systemic increase in the ratio between Foxp $3^{+}$and IL-17-producing $\mathrm{CD}^{+} \mathrm{T}$ cells in healthy pregnancy but not in preeclampsia. J Immunol 183: 7023-7030, 2009.

22. Alijotas-Reig J, Llurba E and Gris JM: Potentiating maternal immune tolerance in pregnancy: A new challenging role for regulatory T cells. Placenta 35: 241-248, 2014.

23. Zhang Z, Liu H, Shi Y, Xu N, Wang Y, Li A and Song W: Increased circulating Th22 cells correlated with Th17 cells in patients with severe preeclampsia. Hypertens Pregnancy 36: 100-107, 2017.

24. Liu W, Putnam AL, Xu-YuZ, Szot GL, Lee MR, Zhu S, Gottlieb PA, Kapranov P, Gingeras TR, Fazekas de St Groth B, et al: CD127 expression inversely correlates with FoxP3 and suppressive function of human CD4 ${ }^{+}$T reg cells. J Exp Med 203: 1701-1711, 2006.

25. Miyara $\mathrm{M}$ and Sakaguchi S: Human FoxP $3^{+} \mathrm{CD} 4^{+}$regulatory T cells: Their knowns and unknowns. Immunol Cell Biol 89: 346-351, 2011

26. Seddiki N, Santner-Nanan B, Martinson J, Zaunders J, Sasson S, Landay A, Solomon M, Selby W, Alexander SI, Nanan R, et al: Expression of interleukin (IL)-2 and IL-7 receptors discriminates between human regulatory and activated T cells. J Exp Med 203 1693-1700, 2006.

27. Aerts NE, Dombrecht EJ, Ebo DG, Bridts CH, Stevens WJ and De Clerck LS: Activated T cells complicate the identification of regulatory T cells in rheumatoid arthritis. Cell Immunol 251: $109-115,2008$

28. Huntzinger E and Izaurralde E: Gene silencing by microRNAs: Contributions of translational repression and mRNA decay. Nat Rev Genet 12: 99-110, 2011.

29. Morales-Prieto DM, Ospina-Prieto S, Chaiwangyen W, Schoenleben M and Markert UR: Pregnancy-associated miRNAclusters. J Reprod Immunol 97: 51-61, 2013.

30. Xu X, Kriegel AJ, Liu Y, Usa K, Mladinov D, Liu H, Fang Y, Ding $\mathrm{X}$ and Liang M: Delayed ischemic preconditioning contributes to renal protection by upregulation of miR-21. Kidney Int 82: $1167-1175,2012$

31. Lin Z, Murtaza I, Wang K, Jiao J, Gao J and Li PF: miR-23a functions downstream of NFATc3 to regulate cardiac hypertrophy. Proc Natl Acad Sci USA 106: 12103-12108, 2009.

32. Shen XC, Lu Y and Qian ZY: Effects of crocetin on the matrix metalloproteinases in cardiac hypertrophy induced by norepinephrine in rats. J Asian Nat Prod Res 8: 201-208, 2006.

33. Bentwich I, Avniel A, Karov Y, Aharonov R, Gilad S, Barad O, Barzilai A, Einat P, Einav U, Meiri E, et al: Identification of hundreds of conserved and nonconserved human microRNAs. Nat Genet 37: 766-770, 2005
34. Pineles BL, Romero R, Montenegro D, Tarca AL, Han YM, Kim YM, Draghici S, Espinoza J, Kusanovic JP, Mittal P, et al: Distinct subsets of microRNAs are expressed differentially in the human placentas of patients with preeclampsia. Am J Obstet Gynecol 196: e261-e266, 2007.

35. Chim SS, Shing TK, Hung EC, Leung TY, Lau TK, Chiu RW and Lo YM: Detection and characterization of placental microRNAs in maternal plasma. Clin Chem 54: 482-490, 2008

36. Mouillet JF, Chu T, Hubel CA, Nelson DM, Parks WT and Sadovsky Y: The levels of hypoxia-regulated microRNAs in plasma of pregnant women with fetal growth restriction. Placenta 31: 781-784, 2010.

37. Zhao M, Wang LT, Liang GP, Zhang P, Deng XJ, Tang Q, Zhai HY, Chang CC, Su YW and Lu QJ: Up-regulation of microRNA-210 induces immune dysfunction via targeting FOXP3 in CD4 ${ }^{+}$ T cells of psoriasis vulgaris. Clin Immunol 150: 22-30, 2014.

38. Auerbach L, Hafner T, Huber JC and Panzer S: Influence of low-dose oral contraception on peripheral blood lymphocyte subsets at particular phases of the hormonal cycle. Fertil Steril 78: 83-89, 2002 .

39. No authors listed: Report of the national high blood pressure education program working group on high blood pressure in pregnancy. Am J Obstet Gynecol 183: S1-S22, 2000.

40. Livak KJ and Schmittgen TD: Analysis of relative gene expression data using real-time quantitative PCR and the $2^{-\Delta \Delta \mathrm{Ct}}$ method. Methods 25: 402-408, 2001.

41. Redman CW, Sacks GP and Sargent IL: Preeclampsia: An excessive maternal inflammatory response to pregnancy. Am J Obstet Gynecol 180: 499-506, 1999.

42. Walker MR, Kasprowicz DJ, Gersuk VH, Benard A Van Landeghen M, Buckner JH and Ziegler SF: Induction of FoxP3 and acquisition of $\mathrm{T}$ regulatory activity by stimulated human $\mathrm{CD}^{+} \mathrm{CD} 25^{-} \mathrm{T}$ cells. J Clin Invest 112: 1437-1443, 2003.

43. Jianjun Z, Yali H, Zhiqun W, Mingming Z and Xia Z: Imbalance of T-cell transcription factors contributes to the Th1 type immunity predominant in pre-eclampsia. Am J Reprod Immunol 63: 38-45, 2010.

44. Saito S, Nakashima A, Shima T and Ito M: Th1/Th2/Th17 and regulatory T-cell paradigm in pregnancy. Am J Reprod Immunol 63: 601-610, 2010.

45. Bettelli E, Carrier Y, Gao W, Korn T, Strom TB, Oukka M, Weiner HL and Kuchroo VK: Reciprocal developmental pathways for the generation of pathogenic effector TH17 and regulatory T cells. Nature 441: 235-238, 2006.

46. Molvarec A, Czegle I, Szijarto J and Rigo J Jr: Increased circulating interleukin-17 levels in preeclampsia. J Reprod Immunol 112: 53-57, 2015.

47. Szarka A, Rigo J Jr, Lazar L, Beko G and Molvarec A: Circulating cytokines, chemokines and adhesion molecules in normal pregnancy and preeclampsia determined by multiplex suspension array. BMC Immunol 11: 59, 2010.

48. Toldi G, Rigo J Jr, Stenczer B, Vasarhelyi B and Molvarec A: Increased prevalence of IL-17-producing peripheral blood lymphocytes in pre-eclampsia. Am J Reprod Immunol 66: 223-229, 2011.

49. Cross D and Cambier JC: Transforming growth factor beta 1 has differential effects on $\mathrm{B}$ cell proliferation and activation antigen expression. J Immunol 144: 432-439, 1990.

50. Travis MA and Sheppard D: TGF- $\beta$ activation and function in immunity. Annu Rev Immunol 32: 51-82, 2014.

51. Bilate AM and Lafaille $\mathrm{JJ}$ : Induced $\mathrm{CD} 4^{+} \mathrm{Foxp}^{+}$regulatory T cells in immune tolerance. Annu Rev Immunol 30: 733-758, 2012.

52. Josefowicz SZ, Lu LF and Rudensky AY: Regulatory T cells: Mechanisms of differentiation and function. Annu Rev Immunol 30: 531-564, 2012.

53. Cretney E, Kallies A and Nutt SL: Differentiation and function of Foxp3 effector regulatory T cells. Trends Immunol 34: 74-80, 2013.

54. Klein S, Kretz CC, Krammer PH and Kuhn A: CD127 low/- and FoxP $^{+}$expression levels characterize different regulatory T-cell populations in human peripheral blood. J Invest Dermatol 130: 492-499, 2010

55. Mazzucchelli R, Hixon JA, Spolski R, Chen X, Li WQ, Hall VL, Willette-Brown J, Hurwitz AA, Leonard WJ and Durum SK: Development of regulatory $\mathrm{T}$ cells requires IL-7R $\alpha$ stimulation by IL-7 or TSLP. Blood 112: 3283-3292, 2008.

This work is licensed under a Creative Commons Attribution-NonCommercial-NoDerivatives 4.0 International (CC BY-NC-ND 4.0) License. 